\title{
Differences on lipid quality index and amino acid profiles of European Anchovy caught from different area in Turkey
}

\section{Demet Kocatepe, Mehmet Emin Erdem, Irfan Keskin, Bayram Köstekli, Yalçin Kaya}

\section{Sinop University, Akliman, Sinop, Turkey}

Keywords:

Anchovy

Amino acid

Fatty acid

EPA

DHA

Article history:

Received 29.01.2019

Received in revised form 15.05.2019

Accepted 30.05.2019

Corresponding author:

Demet Kocatepe

E-mail:

demetkocatepe@

hotmail.com

\section{Abstract}

Introduction. European anchovy is a nutritive food preferred by everybody with high omega 3 contents.

Materials and methods. Within the scope of the study, the anchovy which was caught from different seas in Turkey were compared in view of its lipid quality index and amino acid (AA) profile.

Result and discussion. The amount of SFA, MUFA and PUFA's of the Aegean Sea (AS), Black Sea (BS), and the Marmara Sea (MS) anchovy were 41.31, $11.18,48.10 ; 32.38,31.39,36.24 \%$ and $32.92,32.24$, 34.82 , respectively. The SFA and PUFA in the AS anchovy were found higher than the others $(\mathrm{p}<0.05)$. Similarly, the highest DHA contents were found as $29.51 \%$ in the AS anchovy $(\mathrm{p}<0.05)$ The oleic acid of BS anchovy were more than 3 times of the AS anchovy. Glutamic acid was the highest essential AAs in the groups. The lysine, aspartic acid, alanine, glycine, glutamic acid, 1soleucine, leucine, methionine, phenylalanine, proline in the AS anchovy were higher than the other groups. The histidine of the anchovies was similar $(p>0.05)$. The ratio of EAA with non-EAA of the AS, BS and MS anchovies were found to be 1.21, 1.31 and 1.21 respectively.

Conclusion. It has been found that anchovy contains high amounts of essential fatty acids and EAAs. Especially the AS anchovy was higher quality in view of EPA+DHA and total EAAs compositions.

DOI: $10.24263 / 2310-$

1008-2019-7-1-3 


\section{Introduction}

With increasing demand for quality food throughout the world, the trend towards fish meat has increased. Fish is a nutritive food preferred by young and old people with high protein, mineral matter, water, and unsaturated fat content.

One of the favorite seafoods that can be caught almost all seasons in the territorial waters of our country is the anchovy. European Anchovy (Engraulis encrasicolus Linnaeus, 1758 ) is a pelagic fish species which is preferred by consumers because of its price and taste. Anchovy which is caught during fishing season (September 1- April 15). European anchovy in Turkey is the most important species both in weight and in a value of landings. Annual anchovy caught after the 2000 year in Turkey peaked in the $2001 \mathrm{~s}$ at over 257000 tons but, since then, landings gave declined, averaging 74304 tons for the last 3 years (2015-2017). In 2017, 322.173 tones fish were caught in Turkey land waters. 49\% of all fish caught in our seas were anchovy. 133.766 tons of anchovy were caught from the Black Sea and the others were caught from the Aegean Sea > The Marmara Sea > The Mediterranean Sea. In 2017, the average selling price of 1-kilo anchovy was 5.5TL [1].

In this study, it was investigated the fatty acids, lipid quality index and amino acid contents of the anchovy which were caught from different seas in Turkey.

\section{Material and methods}

The study was carried out in December 2017 with the Anchovy (Engraulis encrasicolus Linnaeus 1758) caught from the Aegean Sea, Black Sea and the Marmara Sea in Turkey. For sampling, twelve kilos fish were obtained from the fisheries at the same time from different regions. The fish were transported to the laboratory under cold storage conditions. And then the fish were filleted and analyzed.

Amino acid analyzes and fatty acids composition were performed after digestion derivatization method according to HPLC pre-column [2] and IID-19 method [3], respectively. Amino acid profiles of the anchovy were calculated as total essential amino acid ( $E$ EAA) including Histidine (His), Threonine (Thr), Arginine (Arg), Valine (Val), Methionine (Met), Phenylalanine (Phe), Isoleucine (Ile), Leucine (Leu), Tyrosine (Tyr) and Lysine (Lys); total non-essential amino acid (इNEAA) including Aspartic acid (Asp), Glutamic acid (Glu), Serine (Ser), Glycine (Gly), Citrulline (Cit), Alanine (Ala) and Proline (Pro); total sweet amino acids ( $\Sigma$ Sweet AA) including Glu, Ser, Gly and Ala; total bitter amino acids ( $\Sigma$ Bitter AA) including His, Arg, Met, Phe, Lys according to Schiffman [4] and Boisen, et al. [5].

Lipid quality indexes of lipid (Atherogenicity index-AI, Thrombogenicity index-TI [6], flesh lipid quality index (FLQ index [7] and hypocholesterolaemic/hypercholesterolaemic ratio $(\mathrm{Hh})[8]$ following formulas were used;

$$
\begin{gathered}
\mathrm{AI}=\left[(\mathrm{C} 12: 0+(4 * \mathrm{C} 14: 0)+(\mathrm{C} 16: 0)] /\left[\left(\sum \mathrm{n} 6+\sum \mathrm{n} 3+\sum \mathrm{MUFA}\right)\right]\right. \\
\mathrm{TI}=[(\mathrm{C} 14: 0+\mathrm{C} 16: 0+\mathrm{C} 18: 0)] /\left[\left(0.5 * \sum \mathrm{MUFA}\right)+\left(0.5 * \sum \mathrm{n} 6\right)+\left(3 * \sum \mathrm{n} 3\right) /\left(\sum \mathrm{n} 6\right)\right] \\
\mathrm{FLQ}=100 *[(\mathrm{EPA} \%+\mathrm{DHA} \%) /(\mathrm{T} \text { tal fatty acids } \%)] \\
\mathrm{Hh}=(\mathrm{C} 18: 1 \mathrm{n}-9+\mathrm{C} 18: 2 \mathrm{n}-6+\mathrm{C} 20: 4 \mathrm{n}-6+\mathrm{C} 18: 3 \mathrm{n}-3+\mathrm{C} 20: 5 \mathrm{n}-3+\mathrm{C} 22: 5 \mathrm{n}-3+\mathrm{C} 22: 6 \mathrm{n}-3) / \\
(\mathrm{C} 14: 0+\mathrm{C} 16: 0)
\end{gathered}
$$

All analyzes were performed in 2 replicates with 3 parallel. The data obtained at the end of the study were evaluated with one-way ANOVA using Minitab Release 17 package program and Tukey test was used for determination of the significance level of differences in-groups and between groups [9]. Figures and schedules are prepared using MS Office 2010 software. 


\section{Results and discussion}

The crude protein, crude fat contents of the Aegean, Black Sea and the Marmara Sea anchovies analyzed were $20.16 \pm 0.29,0.74 \pm 0.01 ; 18.75 \pm 0.30,9.33 \pm 0.75$ and $18.80 \pm 0.12$ $\mathrm{g} / 100 \mathrm{~g}-11.76 \pm 0.61 \mathrm{~g} / 100 \mathrm{~g}$, respectively.

\section{Fatty acids composition of European anchovy oil}

The fatty acid composition results of anchovy oil caught from different seas were in Table 1.

Table 1

Fatty acid composition of Anchovy caught from different seas (\%).

\begin{tabular}{|l|c|c|c|c|c|c|}
\hline & \multicolumn{2}{|c|}{$\begin{array}{c}\text { Aegean Sea } \\
\text { Anchovy }\end{array}$} & \multicolumn{2}{c|}{$\begin{array}{c}\text { Black Sea } \\
\text { Anchovy }\end{array}$} & $\begin{array}{c}\text { Marmara Sea } \\
\text { Anchovy }\end{array}$ \\
\hline & Mean & $\begin{array}{c}\text { Std. } \\
\text { Error }\end{array}$ & Mean & $\begin{array}{c}\text { Std. } \\
\text { Error }\end{array}$ & Mean & $\begin{array}{c}\text { Std. } \\
\text { Error }\end{array}$ \\
\hline Butyric acid (C4:0) & 8.28 & $0.03 \mathrm{a}$ & 2.87 & $0.49 \mathrm{~b}$ & 2.89 & $0.19 \mathrm{~b}$ \\
\hline Caproic acid (C6:0) & 0.01 & $0.00 \mathrm{a}$ & 0.00 & $0.00 \mathrm{~b}$ & 0.00 & $0.00 \mathrm{~b}$ \\
\hline Caprylic acid (C8:0) & 0.00 & $0.00 \mathrm{a}$ & 0.00 & $0.00 \mathrm{a}$ & 0.00 & $0.00 \mathrm{a}$ \\
\hline Capric acid (C10:0) & 0.03 & $0.00 \mathrm{a}$ & 0.01 & $0.00 \mathrm{a}$ & 0.04 & $0.02 \mathrm{a}$ \\
\hline Undecanoik acid (C11:0) & 0.01 & $0.00 \mathrm{a}$ & 0.01 & $0.00 \mathrm{a}$ & 0.01 & $0.01 \mathrm{a}$ \\
\hline Lauric asid (C12:0) & 0.13 & $0.00 \mathrm{~b}$ & 0.13 & $0.00 \mathrm{~b}$ & 0.31 & $0.02 \mathrm{a}$ \\
\hline Tridecanoic acid (C13:0) & 0.13 & $0.00 \mathrm{~b}$ & 0.11 & $0.00 \mathrm{~b}$ & 0.25 & $0.01 \mathrm{a}$ \\
\hline Myristic asid C14:0 & 5.63 & $0.00 \mathrm{~b}$ & 6.07 & $0.02 \mathrm{a}$ & 3.84 & $0.17 \mathrm{c}$ \\
\hline Penta decanoic acid C15:0 & 1.59 & $0.00 \mathrm{~b}$ & 1.84 & $0.04 \mathrm{~b}$ & 2.95 & $0.18 \mathrm{a}$ \\
\hline Palmitic acid C16:0 & 20.24 & $0.74 \mathrm{a}$ & 15.41 & $0.10 \mathrm{~b}$ & 14.91 & $0.89 \mathrm{~b}$ \\
\hline Heptadecanoic acid C17:0 & 1.89 & $0.01 \mathrm{~b}$ & 1.85 & $0.01 \mathrm{~b}$ & 2.68 & $0.16 \mathrm{a}$ \\
\hline Stearic acid C18:0 & 0.01 & $0.00 \mathrm{a}$ & 0.00 & $0.00 \mathrm{~b}$ & 0.00 & $0.00 \mathrm{~b}$ \\
\hline Arachidic acid C20:0 & 0.22 & $0.00 \mathrm{c}$ & 0.72 & $0.00 \mathrm{~b}$ & 1.00 & $0.06 \mathrm{a}$ \\
\hline Heneicosenoic acid C21:0 & 0.05 & $0.00 \mathrm{c}$ & 0.14 & $0.00 \mathrm{~b}$ & 0.19 & $0.01 \mathrm{a}$ \\
\hline Behenic asid C22:0 & 2.62 & $0.01 \mathrm{ab}$ & 2.23 & $0.04 \mathrm{~b}$ & 2.80 & $0.20 \mathrm{a}$ \\
\hline Tricosanoic acid C23:0 & 0.15 & $0.00 \mathrm{~b}$ & 0.27 & $0.00 \mathrm{a}$ & 0.06 & $0.00 \mathrm{c}$ \\
\hline Lignoseric acid (C24:0) & 0.33 & $0.01 \mathrm{c}$ & 0.71 & $0.01 \mathrm{~b}$ & 1.03 & $0.07 \mathrm{a}$ \\
\hline SFA & $\mathbf{4 1 . 3 1}$ & $\mathbf{0 . 8 0 a}$ & $\mathbf{3 2 . 3 8}$ & $\mathbf{0 . 4 4 b}$ & $\mathbf{3 2 . 9 2}$ & $\mathbf{0 . 1 6 b}$ \\
\hline Myristoleic acid (C14:1) & 0.36 & $0.01 \mathrm{~b}$ & 0.55 & $0.01 \mathrm{~b}$ & 1.40 & $0.08 \mathrm{a}$ \\
\hline $\begin{array}{l}\text { Penta decanoic acid } \\
\text { (C15:1)cis-10- }\end{array}$ & 0.20 & $0.00 \mathrm{c}$ & 0.29 & $0.01 \mathrm{~b}$ & 0.55 & $0.01 \mathrm{a}$ \\
\hline Palmitoleic acid C16:1n7 & 0.37 & $0.00 \mathrm{c}$ & 1.72 & $0.01 \mathrm{a}$ & 0.84 & $0.03 \mathrm{~b}$ \\
\hline $\begin{array}{l}\text { Heptadecanoic acid } \\
\text { C17:1cis -10- }\end{array}$ & 0.42 & $0.01 \mathrm{~b}$ & 1.19 & $0.00 \mathrm{a}$ & 1.21 & $0.08 \mathrm{a}$ \\
\hline Oleic acid C18:1n9c & 4.33 & $0.02 \mathrm{c}$ & 14.81 & $0.16 \mathrm{a}$ & 10.59 & $0.71 \mathrm{~b}$ \\
\hline & & & & & & \\
\hline
\end{tabular}




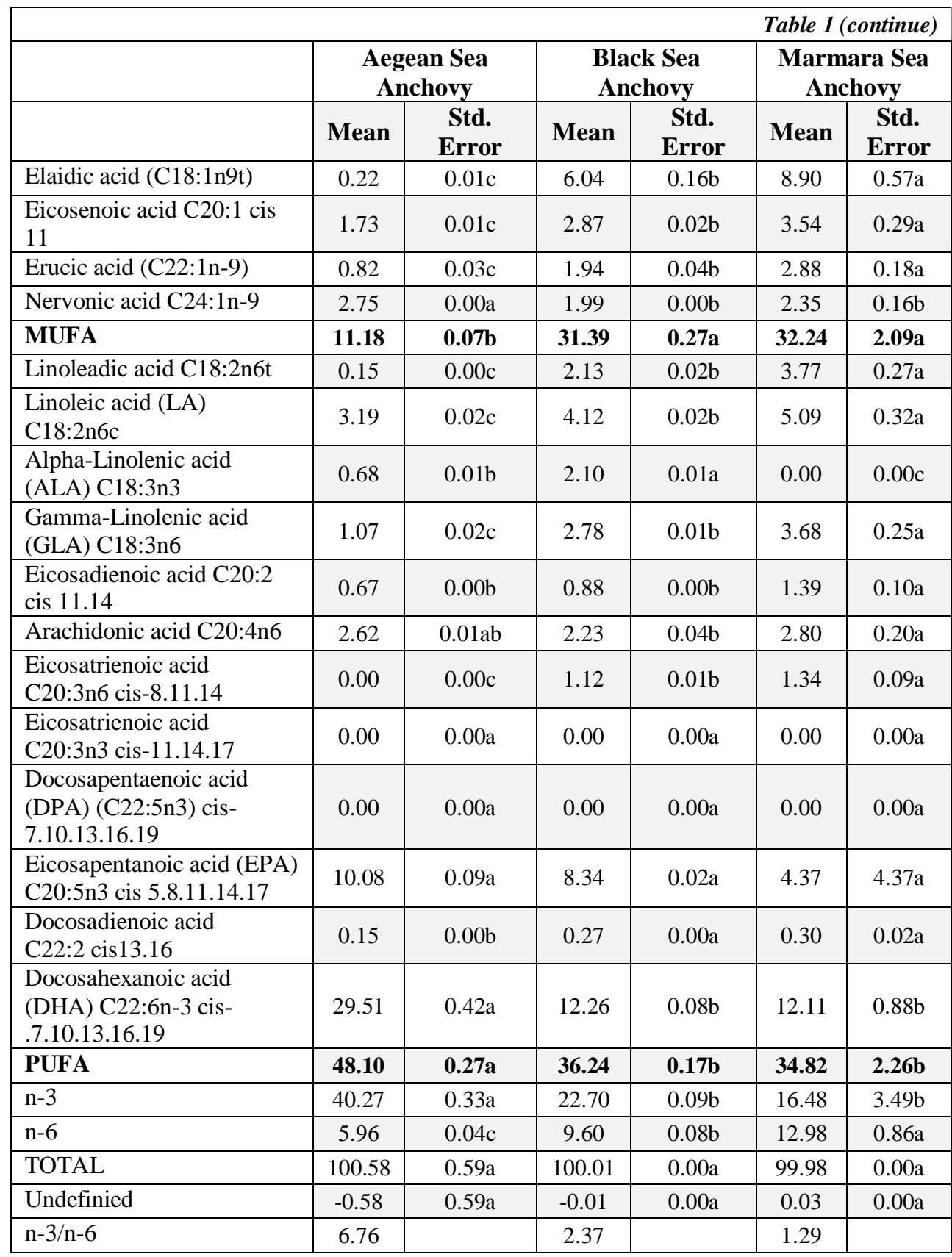

Means with different lowercase letters in the same line are significantly different $(\mathrm{p}<0.05)$ from groups. $\mathrm{p}<0.05$ 


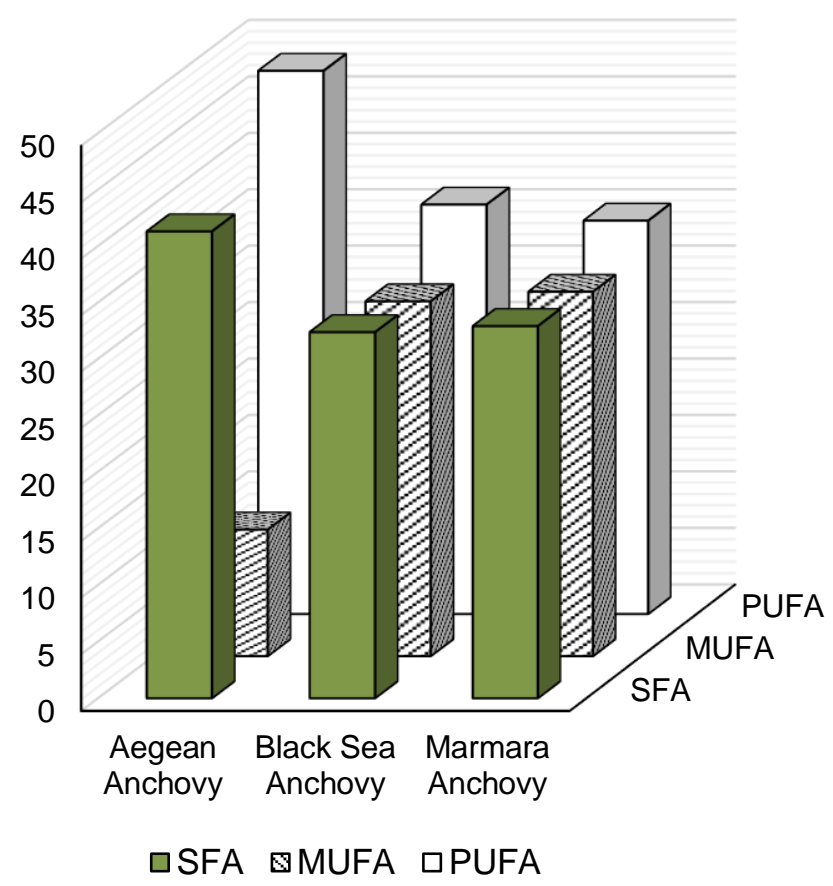

Figure 1. The total fatty acids composition of anchovy (\%).

The amount of SFA (saturated fatty acids), MUFA (monounsaturated fatty acids) and PUFA (polyunsaturated fatty acids) of anchovy was max. $41.31 \%$ (in the Aegean Sea anchovy), max. 32.24\% (in the Marmara Sea anchovy) and max. $48.10 \%$ (in the Aegean Sea anchovy), respectively (Figure 1). A large amount of SFA content is composed of palmitic acid (max 20.24\% in the Aegean Sea anchovy), butyric acid (max 8.28\% in the Aegean Sea anchovy), myristic acid (max $6.07 \%$ in Black Sea anchovy) and behenic acid (max $2.80 \%$ in the Marmara Sea anchovy). While about $47 \%$ of the MUFAs composed of oleic acid in Black Sea anchovy. The predominant $\mathrm{n} 3$ fatty acids found in fish meat is especially DHA. Similarly, present study; Özden [10] and Kocatepe and Turan [11] were reported the predominant SFA, MUFA, and PUFA's in the Marmara Sea anchovy were; palmitic acid, oleic acid, and EPADHA, respectively.

Fish fats contain $20-30 \%$ of saturated fatty acids, $70-80 \%$ of unsaturated fatty acids [12, 13]. In the present study the fatty acids content of anchovies was compared, it was seen that the amount of SFA, MUFA and PUFA were changed between $32 \%-42 \%, 11 \%-33 \%$ and $34 \%-49 \%$. respectively.

The SFA contents of the Aegean Sea anchovy was highest ( $p>0.05)$. Researchers reported the different SFA ratios were 40.77\% [14] in the Marmara Sea anchovy; 38.62, 35.20 and $33.57 \%$ in November, December and January in the Black Sea anchovy [15], 37.91 to $34.04 \%$ (from October to April) in the Black Sea anchovy [16]; $42.2 \%$ in the Black sea and the Marmara Sea [17], 36.23\% in the Marmara Sea anchovy [10] and 37.81\% [18].

Most of the $n-6$ fatty acids form was linoleic acid and arachidonic acid in all groups. The $n-3 / n-6$ ratio is the best index for comparing relative nutritional values of fish oils from 
different species [19]. In the study, the maximum n-3/n-6 proportional value was determined as 6.76 in the Aegean Sea anchovy, 2.37 in Black sea anchovy and 1.29 in the Marmara Sea anchovy, respectively.

The minimum value of the PUFA/SFA ratio recommended is 0.45 [20]. PUFA/SFA ratio of anchovy was higher than the limit value in all groups (Table 2).

Table 2

PUFA/SFA ratio, lipid quality indices, crude lipid and EPA+DHA value (to meet the EPA and DHA recommendation) of whiting meat and roe (\%).

\begin{tabular}{|l|c|c|c|}
\hline & $\begin{array}{c}\text { Aegean Sea } \\
\text { Anchovy }\end{array}$ & $\begin{array}{c}\text { Black Sea } \\
\text { Anchovy }\end{array}$ & $\begin{array}{c}\text { Marmara Sea } \\
\text { Anchovy }\end{array}$ \\
\hline PUFA/SFA & 1.17 & 1.13 & 1.06 \\
\hline AI & 0.75 & 0.62 & 0.49 \\
\hline TI & 0.19 & 0.24 & 0.26 \\
\hline FLQ & 39.37 & 16.48 & 19.01 \\
\hline h/H & 1.98 & 2.51 & 2.81 \\
\hline Crude lipid\% & 0.74 & 11.76 & 9.33 \\
\hline EPA+DHA & 0.29 & 2.42 & 1.54 \\
\hline
\end{tabular}

Flesh Lipid Quality Indices (FLQ) indicate the global dietetic quality of lipids and their potential effects on the development of coronary disease [21]. The FLQ values of the Aegean Sea anchovy was highest. AI and IT indexes should be low to prevent cardiovascular diseases related with lipid intake [6] and the high value of $\mathrm{h} / \mathrm{H}$ ratio represents high-quality lipids. In this study, AI and IT indexes were measured to be lower than 1.0 but high in $\mathrm{h} / \mathrm{H}$ in all groups. Ouraji et al. [22] and Stancheva et al. [23] determined that higher values of AI and IT (>1.0) are detrimental to human health. Especially the h/H ratio of the Marmara Sea anchovy was higher than the others. It was showed that the lipids quality of the Aegean Sea anchovy had the highest quality in view of the lipid quality.

The ratio of n-3/n- 6 fatty acid is commonly used as an index for assessing the nutritional quality of fishery products [24]. The ratio of $n-3 / n-6$ of the Aegean Sea anchovy was the highest (6.76). The maximum amount of $n 3$ and $n 6$ were detected in the Aegean Sea anchovy and the Marmara Sea anchovy, respectively. Several studies report that a high n-6/n-3 FA ratio is associated with an increased risk of CRC (colorectal cancer), PC (Pancreatic cancer) and BC (breast cancer). Since a risk associated with n- 6 has not been demonstrated, it can be concluded that a low n-3 PUFA intake is responsible for the observation [25]. The difference in the fatty and fatty acid composition of seafood depends on different factors such as nutritional pattern, geographical conditions. environmental temperature, season, hunting area, fish size, sex and species $[13,26]$.

For adult pregnant and lactating females, the minimum intake for optimal adult health and fetal and infant development is $0.3 \mathrm{~g} / \mathrm{d}$ EPA+DHA, of which at least $0.2 \mathrm{~g} / \mathrm{d}$ should be DHA [25]. Similarly, the British Nutrition Foundation [27] has emphasized that people who care for balanced and healthy nutrition should get $0.2 \mathrm{~g}$ of EPA + DHA every day. Daily intake of $100 \mathrm{~g}$ anchovy consumption (caught from all sea studied in this study) is meet the $\mathrm{EPA}+\mathrm{DHA}$ requirement. This study was indicating that the very oily Black sea anchovy has more EPA+DHA than the others. Especially the crude fat value of the Aegean Sea anchovy was very low, for this reason to meet the EPA and DHA recommendation was lowest according to the BNF. 


\section{Amino acids composition of European anchovy}

The results of the amino acid compositions of the anchovies caught from different seas were shown in Table 3. Total nine essential amino acids except from tryptophan and nine non- essential amino acids were identified in the anchovy. The maximum amount of glutamic acid detected in the Aegean Sea anchovy $(\mathrm{p}<0.05)$. The content of aspartic acid in the Black Sea and the Marmara Sea anchovies were found to be similar ( $p>0.05)$.

The highest amount of essential amino acids was detected for lysine in all groups. The amount of lysine was lowest in the Marmara Sea anchovy. The ratio of essential amino acids to non-essential amino acids (EA/non-EA) in fish meat was found to be 1.21 in the Aegean and Marmara Sea anchovy and 1.31 in Black Sea anchovy.

Amino acid composition of anchovy caught from different Sea (mg/kg).

Table 3

\begin{tabular}{|c|c|c|c|c|c|c|}
\hline & \multicolumn{2}{|c|}{$\begin{array}{c}\text { Aegean Sea } \\
\text { Anchovy }\end{array}$} & \multicolumn{2}{|c|}{$\begin{array}{l}\text { Black Sea } \\
\text { Anchovy }\end{array}$} & \multicolumn{2}{|c|}{$\begin{array}{c}\text { Marmara Sea } \\
\text { Anchovy }\end{array}$} \\
\hline & Mean & $\begin{array}{c}\text { Std. } \\
\text { Error }\end{array}$ & Mean & $\begin{array}{c}\text { Std. } \\
\text { Error }\end{array}$ & Mean & $\begin{array}{c}\text { Std. } \\
\text { Error }\end{array}$ \\
\hline Alanine & 1.68 & $0.02 \mathrm{a}$ & 1.35 & $0.04 \mathrm{~b}$ & 1.24 & $0.01 \mathrm{~b}$ \\
\hline Arginine* & 1.53 & $0.01 \mathrm{a}$ & 1.37 & $0.05 a$ & 1.17 & $0.02 \mathrm{~b}$ \\
\hline Aspartic Acid & 2.39 & $0.07 \mathrm{a}$ & 1.88 & $0.03 b$ & 1.85 & $0.04 \mathrm{~b}$ \\
\hline Cysteine & 0.32 & $0.00 \mathrm{a}$ & 0.31 & $0.01 \mathrm{a}$ & 0.24 & $0.00 \mathrm{~b}$ \\
\hline Glutamic Acid & 3.35 & $0.04 \mathrm{a}$ & 2.92 & $0.02 b$ & 2.47 & $0.02 \mathrm{c}$ \\
\hline Glycine & 1.05 & $0.01 \mathrm{a}$ & 0.59 & $0.01 \mathrm{~b}$ & 0.83 & $0.03 \mathrm{c}$ \\
\hline Histidine* & 1.11 & $0.01 \mathrm{a}$ & 0.93 & $0.09 a$ & 0.83 & $0.06 \mathrm{a}$ \\
\hline Isoleucine* & 0.93 & $0.02 \mathrm{a}$ & 0.78 & $0.02 \mathrm{~b}$ & 0.70 & $0.03 \mathrm{~b}$ \\
\hline Leucine* & 1.88 & $0.01 \mathrm{a}$ & 1.56 & $0.05 b$ & 1.43 & $0.00 \mathrm{~b}$ \\
\hline Lysine* & 2.95 & $0.15 \mathrm{a}$ & 2.80 & $0.12 \mathrm{ab}$ & 2.24 & $0.04 \mathrm{~b}$ \\
\hline Methionine* & 0.80 & $0.03 \mathrm{a}$ & 0.58 & $0.01 \mathrm{~b}$ & 0.62 & $0.02 \mathrm{~b}$ \\
\hline Ornithine & 0.06 & $0.01 \mathrm{a}$ & 0.07 & $0.01 \mathrm{~s}$ & 0.06 & $0.01 \mathrm{a}$ \\
\hline Phenylalanine* & 1.16 & $0.00 \mathrm{a}$ & 0.98 & $0.02 b$ & 0.91 & $0.00 \mathrm{c}$ \\
\hline Proline & 0.99 & $0.01 \mathrm{a}$ & 0.81 & $0.00 \mathrm{~b}$ & 0.77 & $0.01 \mathrm{~b}$ \\
\hline Serine & 1.19 & $0.03 \mathrm{a}$ & 1.03 & $0.07 \mathrm{~s}$ & 0.94 & $0.06 \mathrm{a}$ \\
\hline Threonine* & 1.27 & $0.04 \mathrm{a}$ & 1.13 & $0.06 \mathrm{sb}$ & 0.97 & $0.00 \mathrm{~b}$ \\
\hline Tyrosine & 0.93 & $0.04 \mathrm{a}$ & 0.76 & $0.04 \mathrm{~s}$ & 0.75 & $0.03 a$ \\
\hline Valine* & 1.30 & $0.03 \mathrm{a}$ & 1.31 & $0.02 \mathrm{~s}$ & 1.03 & $0.01 \mathrm{~b}$ \\
\hline Taurine & 0.38 & $0.02 \mathrm{a}$ & 0.32 & $0.00 \mathrm{~s}$ & 0.35 & $0.01 \mathrm{a}$ \\
\hline Total amino acids & 25.26 & $0.31 \mathrm{a}$ & 21.46 & $0.25 b$ & 19.39 & $0.15 \mathrm{c}$ \\
\hline $\begin{array}{l}\text { Total Essential amino acids } \\
\text { (EA) }\end{array}$ & 13.86 & $0.15 \mathrm{a}$ & 12.18 & $0.14 \mathrm{~b}$ & 10.64 & $0.14 \mathrm{c}$ \\
\hline $\begin{array}{l}\text { Total non-essential amino } \\
\text { acids(NEA) }\end{array}$ & 11.41 & $0.15 \mathrm{a}$ & 9.27 & $0.11 \mathrm{~b}$ & 8.75 & $0.01 b$ \\
\hline Sweet amino acids & 7.28 & $0.10 \mathrm{a}$ & 5.88 & $0.07 \mathrm{~b}$ & 5.48 & $0.02 \mathrm{~b}$ \\
\hline Bitter amino acids & 7.55 & $0.13 \mathrm{a}$ & 6.66 & $0.18 b$ & 5.76 & $0.12 \mathrm{c}$ \\
\hline EA/NEA & 1.21 & & 1.31 & & 1.21 & \\
\hline
\end{tabular}


Fish meat is a protein source with high nutritive value. In fish meat containing all essential amino acid as aspartic acid. glutamic acid and lysine [28]; aspartic acid and glutamic acid are important amino acids that play a role in enzyme activation, preservation of the solubility and ionic character of proteins. One of the most important sources (50-85\%) of non-protein nitrogen in fish meat is free amino acids. Free amino acids give the fish meat a characteristic taste.

The level of total sweet AA components was higher in the Aegean Sea anchovy $(p<0.05)$ than the other anchovies, total bitter AA was also higher than when compared the other groups. Proteins are composed of 20 different amino acids. Most proteins contain glutamate in high content. For example, glutamate contents of casein in milk, gluten in wheat, glycine in soybean, and myosin in muscle are $21-35 \%$. Although free glutamate has umami taste, glutamate in proteins has no taste. Proteolysis during fermentation produces free glutamate in high content [29]. Umami taste is found in foods rich in glutamates such as fish, meat, milk, tomatoes, and some vegetables. In addition, the umami flavor is enriched with certain ribonucleotides (inosine and guanosine nucleotides) found in some meats and fish [29-31]. Foods rich in glutamate content, when combined with ribonucleotides, have a higher taste intensity than the sum of both contents [30, 31]. An important component of umami taste is glutamic acid. Glutamate is an amino acid that is very common in foods [32]. The glutamic acid contents of the Aegean Sea anchovy were highest. It can be said that; the umami taste of the Aegean Sea anchovy is more dominant.

The World Health Organization's [33] on protein and amino acid requirements for human nutrition reports an adult daily protein intake of $0.83 \mathrm{~g} / \mathrm{kg}$, with essential amino acids; leucine 59 $\mathrm{mg} / \mathrm{g}$, lysine $45 \mathrm{mg} / \mathrm{g}$, isoleucine $30 \mathrm{mg} / \mathrm{g}$, threonine $23 \mathrm{mg} / \mathrm{g}$ and methionine $16 \mathrm{mg} / \mathrm{g}$. In the present study, about $80 \mathrm{~g}$ anchovy meat daily consumption meets the leucine, lysine, 1soleucine, threonine and methionine requirements. In addition, $320 \mathrm{~g}$ anchovy consumption enough for daily protein requirements (Table 4).

Anchovy amounts to meet the recommended daily intake (g).

Table 4

\begin{tabular}{|l|c|c|c|c|}
\hline & $\begin{array}{c}\text { Recommended } \\
\text { Daily Intake* }\end{array}$ & $\begin{array}{c}\text { Aegean Sea } \\
\text { Anchovy }\end{array}$ & $\begin{array}{c}\text { Black Sea Sea } \\
\text { Anchovy }\end{array}$ & $\begin{array}{c}\text { Marmara Sea } \\
\text { Anchovy }\end{array}$ \\
\hline Protein & $60 \mathrm{~g} * *$ & $291 \mathrm{~g}$ & $319 \mathrm{~g}$ & $320 \mathrm{~g}$ \\
\hline Leucine & $59 \mathrm{mg} / \mathrm{g}$ & $64.5 \mathrm{~g}$ & $77.7 \mathrm{~g}$ & $71.3 \mathrm{~g}$ \\
\hline Lysine & $45 \mathrm{mg} / \mathrm{g}$ & $31.05 \mathrm{~g}$ & $37.8 \mathrm{~g}$ & $30.2 \mathrm{~g}$ \\
\hline Isoleucine & $30 \mathrm{mg} / \mathrm{g}$ & $66.3 \mathrm{~g}$ & $80.7 \mathrm{~g}$ & $72.4 \mathrm{~g}$ \\
\hline Threonine & $23 \mathrm{mg} / \mathrm{g}$ & $37.3 \mathrm{~g}$ & $44.5 \mathrm{~g}$ & $38.2 \mathrm{~g}$ \\
\hline Methionine & $16 \mathrm{mg} / \mathrm{g}$ & $41.1 \mathrm{~g}$ & 48.6 & $51.7 \mathrm{~g}$ \\
\hline
\end{tabular}

\section{Conclusion}

Fatty acid and amino acid composition of anchovy caught from different seas in Turkey are different from each other. In generally the European anchovy is a good source of n-3 PUFA. Especially the maximum amount of $\mathrm{n} 3$ and $\mathrm{n} 6$ have detected in the Aegean Sea anchovy and the lipids quality of the Aegean Sea anchovy had the highest quality in view of the lipid quality index. But the crude lipid composition of Black Sea anchovy was highest, for this reason, Black sea anchovy has more EPA+DHA than the others. Especially the crude fat value of the Aegean Sea anchovy was very low, and to meet the EPA and DHA recommendation was lowest according to the BNF. The amino acid composition of anchovies was different from each other, about $80 \mathrm{~g}$ European anchovy meet the daily consumption requirements of the leucine, lysine, 1soleucine, threonine, and methionine. 


\section{References}

1. TUIK (2018), Turkish Statistical Institute, Fisheries Statistics, Available at: http://www.tuik.gov.tr/PreTablo.do?alt_id=1005.

2. Anonymous (1998), Amino acid analyzer LC 3000 operation manual (AAAOM) sample preparation for physiological fluids (Tissue Extract), In: Manual version 4.1. of Eppendorf Biotronik Co., pp. 65-81.

3. IUPAC (1979,) Standard methods for analysis of oils, fats and derivatives, 6th edn. (5th edn. Method II.D.19), Pergamon Press Oxford, Oxford.

4. Boisen S., Hvelplund T., Weisbjerg MR. (2000), Ideal amino acid profiles as a basis for feed protein evaluation, Livestock Production Science, 64(2-3), pp. 239-251, DOI: 10.1016/S0301-6226(99)00146-3.

5. Schiffman S.S. (1975), Taste of nutrients: Amino acids, vitamins, and fatty acids. Perception \& Phschophysics, 17(2), pp. 140-146, DOI: 10.3758/BF03203878.

6. Ulbricht T., Southgate D. (1991), Coronary heart disease: seven dietary factors, The Lancet, 338, pp. 985-992, DOI: 10.1016/0140-6736(91)91846-M.

7. Abrami G., Natiello F., Bronzi P., McKenzie D.J., Bolis L., Agradi E. (1992), A comprosion of highly unsaturated fatty acid levels in wild and farmed eels (Anguilla anguilla), Comparative biochemistry and physiology. B. Comparative biochemistry, 101(1-2), pp. 79-81, DOI: 10.1016/0305-0491(92)90161-J.

8. Santos-Silva J., Bessa R.J.B., Santos-Silva F. (2002), Effect of genotype. feeding system and slaughter weight on the quality of light lambs. II Fatty acid composition of meat. Livestock Production Science, 77, pp. 187-194, DOI: 10.1016/S0301-6226(02)00059-3

9. Sümbüloğlu K., Sümbüloğlu V. (2007), Biyoistatistik. Hatipoğlu Yayınları.

10. Özden Ö. (2005), Changes in amino acid and fatty acid composition during shelf-life of marinated fish, Journal of the science of Food and Agriculture, 85, pp. 2015-2020. DOI: $10.1002 /$ jsfa. 2207

11. Kocatepe D., Turan H. (2012), Proximate and fatty acid composition of some commercially important fish species from the Sinop region of the Black Sea. Lipids, 47(6), pp. 635-41, DOI: 10.1007/s11745-012-3658-1.

12. Gökoğlu N. (2002), Su Ürünleri İşleme Teknolojisi. Su Vakfi Yayınları. Haziran 2002.

13. Çaklı Ş., (2007), Su Ürünleri İşleme Teknolojisi -1 (Su Ürünleri İşleme Teknolojisinde Temel Konular), Ege Üniversitesi Yayınları. Su Ürünleri Fakültesi Yayın no: 76. İzmir.

14. Güner S., Dincer B., Alemdag N., Colak A., Tüfekci M. (1998), Proximate composition and selected mineral content of commercially important fish species from the Black Sea. Journal of the Science of Food Agriculture, 78, 337-342. DOI: 10.1002/(SICI)10970010(199811)78:3<337; AID-JSFA122>3.0.CO;2-A

15. Kaya Y., Turan H. (2008), Comparison of protein, lipid and fatty acids composition of anchovy (Engraulis encrasicolus L. 1758) during the commercial catching season, Journal of Muscle Foods, 21, pp. 474-483. DOI: 10.1111/j.1745-4573.2009.00196.x

16. Öksüz A., Özyılmaz A. (2010), Changes in fatty acid compositions of Black Sea Anchovy (Engraulis encrasicolus L.1758) during catching season. Turkish Journal of Fisheries and Aquatic Science, 10, pp. 3812-385, DOI: 10.4194/trjfas.2010.0311

17. Tanakol R., Yazıcı Z., Sener E., Sencer E. (1999), Fatty acid composition of 19 species of fish from the Black Sea and the Marmara Sea, Lipids, 34(3), pp. 291-297. DOI: 10.1007/s11745-999-0366-8

18. Bayır A., Haliloglu H.I., Sirkecioglu A.N., Aras N.M. (2006), Fatty acid composition in some selected marine fish species living in Turkish waters, Journal of the Science of Food and Agriculture, 86, pp. 163-168. DOI: 10.1002/jsfa.2295.

19. Piggott G.M., Tucker B.W. (1990), Seafood effects of Technology on Nutrition, Marcel Dekker. New York. 
20. HMSO UK. (1994), Nutritional aspects of cardiovascular disease (report on health and social subjects No.46, London.

21. Senso L., Suarrez M.D., Ruiz-Cara T., Garcira-Gallego M. (2007), On the possible effects of harvesting season and chilled storage on the fatty acid profile of the fillet of farmed gilthead sea bream (Sparus aurata), Food Chemistry, 101, pp. 298-307. DOI: 10.1016/j.foodchem.2006.01.036.

22. Ouraji H., Shabanpur B., Abediankenari A., Shabani A., Nezami A., Sudagar M., Faghani S. (2009), Total lipid. fatty acid composition and lipid oxidation of Indian white shrimp (Fenneropenaeus indicus) fed diets containing different lipid sources. Journal of the Science of Food and Agriculture, 89(6), pp. 993-997, DOI: 10.1002/jsfa.3545.

23. Stancheva M., Merdzhanova A., Dobreva D.A., Makedonski L. (2014), Common carp (Cyprinus carpio) and European catfish (Silurus glanis) from Danube River as sources of fat soluble vitamins and fatty acids, Czech Journal of Food Sciences, 32, pp. 16-24, DOI: $10.17221 / 31 / 2013-C J F S$.

24. Chen D.W., Zhang M. (2007), Non-volatile taste active compounds in the meat of Chinese mitten crab (Eriocheir sinensis), Food Chemistry, 104, pp. 1200-1205, DOI: 10.1016/j.foodchem.2007.01.042

25. FAO (2008), FAO Food and Nutrition Paper 91. Fats and fatty acids in human nutrition. Report of an expert consultation. 10-14 November 2008. Geneva. Available at: http://www.fao.org/3/a-i1953e.pdf

26. Alasalvar C., Taylor K.D.A., Zubcov E., Shahidi F., Alexis M. (2002), Differentiation of cultured and wild sea bass (Dicentrarchus labrax), pp. total lipid content. fatty acid and trace mineral composition. Food Chemistry, 79, pp. 145-150, DOI: 10.1016/S03088146(02)00122-X

27. British Nutrition Foundation (BNF) (1992), Unsaturated Fatty Acids. Nutritional and Physiological Significance. Report of British Nutrition Foundation. Chapman and Hall. London, pp. 152-163.

28. Oladapo A.A., Omosola A.A., Olusegun L.O. (1984), Quality changes of Nigerian traditionally processed freshwater fish species, nutritive and drgnoleptic changes, $J$ Food Sci, 9, pp. 333-340.

29. Kurihara K. (2015), Umami the Fifth Basic Taste: History of Studies on Receptor Mechanisms and Role as a Food. Flavor, Biomed Research International, 4(13), pp. 15, http://dx.doi.org/10.1155/2015/189402.

30. Yamaguchi S. (1967), The Synergistic Taste Effect of Monosodium Glutamate and Disodium 5-İnosinate. Journal Food Science, 32, pp. 473-478, DOI: 10.1111/j.13652621.1967.tb09715.x

31. Rifkin B., Bartoshuk L.M. (1980), Taste Synergism Between Monosodium Glutamate and Disodium 5- Guanylate. Physiology Behavior, 24, pp. 1169-1172, DOI: 10.1016/0031-9384(80)90066-9

32. Cömert M., Güdek M. (2017), Fifth taste: Umami. Journal of Tourism and Gastronomy, 5(3), pp. 397-408, DOI: 10.21325/jotags.2017.101.

33. World Health Organization (WHO) (2007), Protein and amino acid requirements in human nutrition (Vol. 935), World Health Organization. 